\title{
Suitability of rocks and sediments from Brzeszcze and Silesia coal mines as building materials in terms of radiological hazard
}

Monika Śleziak, Marek Duliński

\begin{abstract}
The isotope activity concentration of rocks and bottom sediments was evaluated based on the samples collected from sedimentation ponds and gangue repositories. Radium ${ }^{226} \mathrm{Ra}$, thorium ${ }^{228} \mathrm{Th}$ and potassium ${ }^{40} \mathrm{~K}$ activities were measured by gamma spectrometry using high-purity germanium detector - HPGe 4020. The radiation effect resulting from the presence of natural radionuclides was estimated by radiological hazard indices such as $f_{1}$ and $f_{2}$ coefficients, radium equivalent, internal and external hazard indices and absorbed dose rate. Performed measurements and calculations have shown that the bottom sediments are most contaminated. They may pose a serious radiological hazard for present and future generations.
\end{abstract}

Keywords: dosing tanks • radiological hazard • K-40 • Ra-226 • Th-228

\author{
M. Śleziak ${ }^{\bowtie}$ M. Duliński \\ Faculty of Physics and Applied Computer Science \\ AGH University of Science and Technology \\ 30 Mickiewicza Ave., 30-059 Kraków, Poland \\ E-mail: monika.sleziak@gmail.com
}

Received: 31 October 2017

Accepted: 1 February 2019

\section{Introduction}

Exploitation of coal is inevitably bound up with the necessity of dewatering of mines and removal of gangue. Water and rocks are treated as waste products. In Polish mines, both water and rocks contain elevated concentrations of natural radionuclides, mostly radium and thorium. These isotopes in water environment, due to coprecipitation or adsorption on particles, are removed from the water column and buried in bottom sediments. Waste rocks (ca. $0.4 \mathrm{t}$ of rock per ton of coal derived from the Brzeszcze and Silesia coal mines) are stored in gangue repositories and form reservoirs of elevated concentrations of radioactive isotopes [1].

Radium ${ }^{226} \mathrm{Ra}$, thorium ${ }^{228} \mathrm{Th}$ and potassium ${ }^{40} \mathrm{~K}$ activity concentrations in rocks and sediments from Brzeszcze and Silesia mines have been used for the estimation of radiological hazard associated with exposure on radiation and potential usage of these materials in its pure form in construction industry. Coefficients $f_{1}$ and $f_{2}$, radium equivalent, internal and external hazard indices and absorbed dose rate are the most important parameters used in the appraisal of rocks and sediments.

The problem of radioactivity of classical or new building materials is widely discussed in the literature [2-5], but there is lack of information about radiation hazard related to use of waste products in building industry. Three locations of sludge storage

\footnotetext{
*This paper is based on a poster presentation showed at NUTECH-2017 Conference, 10-13 September 2017, Kraków, Poland.
} 


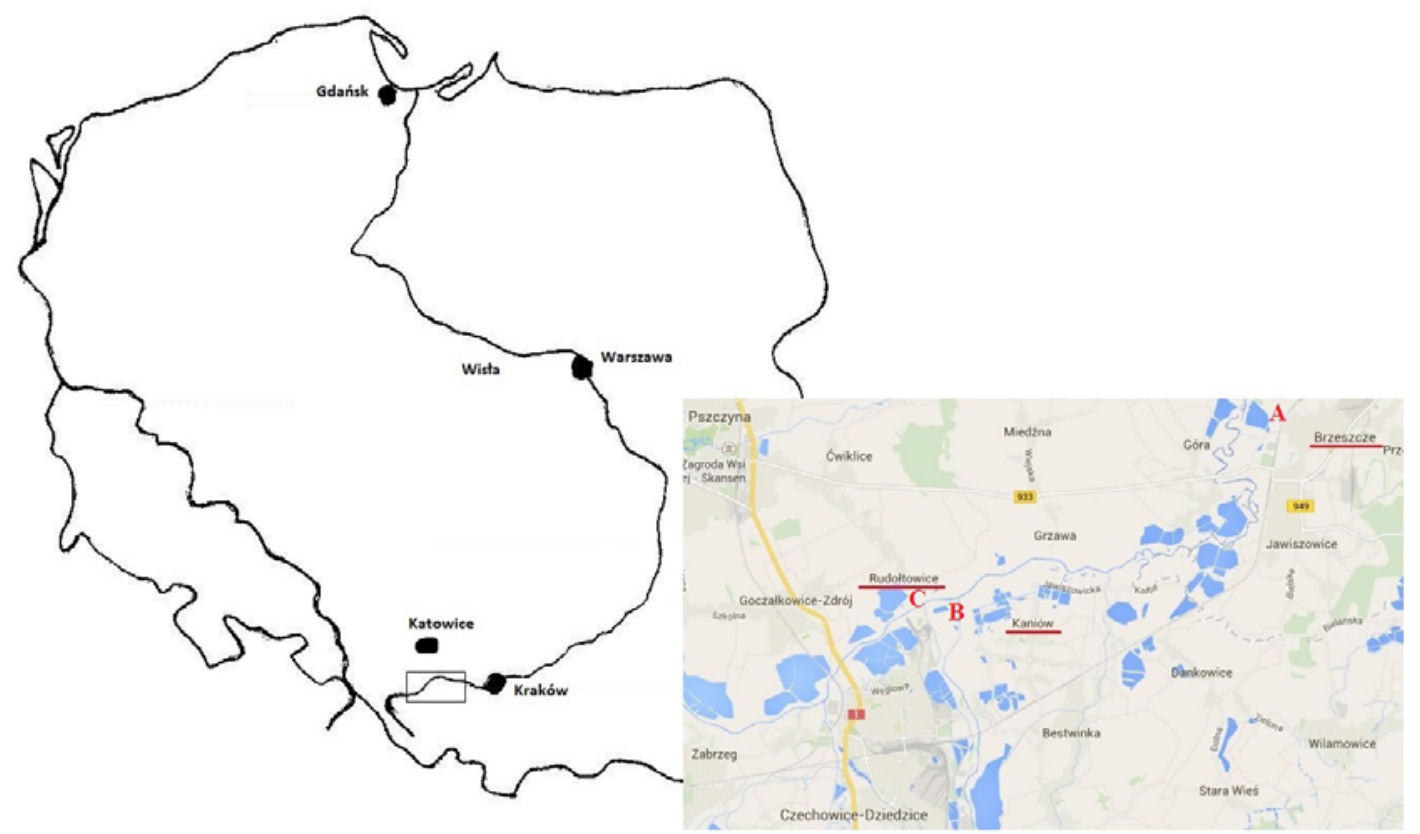

Fig. 1. Location of the studied area (Google maps).

have been chosen for the investigation of suitability of mining post-production wastes as construction materials. Two of them (Kaniów and Rontok Duży ponds) contain wastes from the Silesia coal mine, whereas in the third place wastes from the Brzeszcze mine are stored. The sedimentation ponds and stores of waste material are located in Małopolska and Silesia regions (Fig. 1). Bottom sediments and waste rocks stored in these locations have been never assessed in terms of radiological hazard arising from their application in building and construction industries.

\section{Measurement methodology}

\section{Sampling collection}

To estimate the radiological hazard from the waste products such as bottom sediments or rocks, the following sampling places were chosen: the gangue repositories adjoining the dosing tanks, embankments of the ponds and rivers as well as bottom sediments.

During the high water level, samples of bottom sediments were collected using a special gimlet. When the sediments were uncovered, samples were taken from the $10-\mathrm{cm}$ thick surface layer. Samples were collected at the inlet area, the coastal zone and the middle part of reservoirs. Location of the bottom sediment sampling points within the investigated water reservoirs is shown in Fig. 2. The rock samples were collected from enumerated locations representing different types of rocks. The weight of each sample was equal to 1-2 kg. All samples were collected between 2009 and 2013.

\section{Gamma spectrometry measurements}

Collected samples were dried for 24 hours at $105^{\circ} \mathrm{C}$, crumbled, homogenized and sieved. Then, they were closed in aluminium cylindrical containers $(70 \mathrm{~mm}$ in diameter, $31.5 \mathrm{~mm}$ height). After 21 days when the radioactive equilibrium between radium and its short-lived decay products was achieved, the activity concentration was measured using high-purity germanium detector Canberra HPGe 4020. The detector's energy resolution was equal to 0.8 and $0.2 \%$ for the 122 and $1332 \mathrm{keV}$ energy peaks, respectively.

The concentration of radioactive isotopes such as radium ${ }^{226} \mathrm{Ra}$ and thorium ${ }^{228} \mathrm{Th}$ was determined by their decay products. The radium activity was determined by ${ }^{214} \mathrm{Bi}(609.3,1120.3$ and $1764.5 \mathrm{keV}$ ) and that of thorium by ${ }^{208} \mathrm{Tl}$ ( 583.2 and $2614.5 \mathrm{keV})$. As well, the concentration of potassium ${ }^{40} \mathrm{~K}$ was determined from its peak at $1460.8 \mathrm{keV}$. The detection limit was equal to $1 \mathrm{~Bq} \cdot \mathrm{kg}^{-1}$ for radium ${ }^{226} \mathrm{Ra}$, thorium ${ }^{228} \mathrm{Th}$ and potassium ${ }^{40} \mathrm{~K}$. Counts were collected for 20 hours [2,6]. Calibration was performed using RGK-1, RGU-1 and RGTh-1 reference materials distributed by the International Atomic Energy Agency (IAEA). The relative uncertainties of the specific activity for these materials are equal to $0.33,0.25$ and $1 \%$, respectively [7].

\section{Indicators of radiological hazard}

Measured concentrations of natural radioisotopes in rocks and bottom sediments exceed typical values recorded in soils in Poland. The assessment of their suitability as construction materials is a subject of legal regulations of the Polish Ministry Board [8]. These regulations concern ${ }^{40} \mathrm{~K},{ }^{226} \mathrm{Ra}$ and ${ }^{228} \mathrm{Th}$ isotopes and are in accordance with the recommendations of European Commission [9, 10]. They define two coefficients, $f_{1}$ and $f_{2}$, which should be calculated for each building material and compared with reference values resulting from maximum allowable concentrations of the mentioned radionuclides. Other radiological exposure indicators are 
also used in the literature with the aim of better determination of risk from ionizing radiation.

It is worth to mention here about differences in thorium isotope treatment in Polish and European legislations. In the calculation of parameters determining radiological hazard, Polish regulations recommend ${ }^{228} \mathrm{Th}$ instead of ${ }^{232} \mathrm{Th}$. Therefore, in calculations
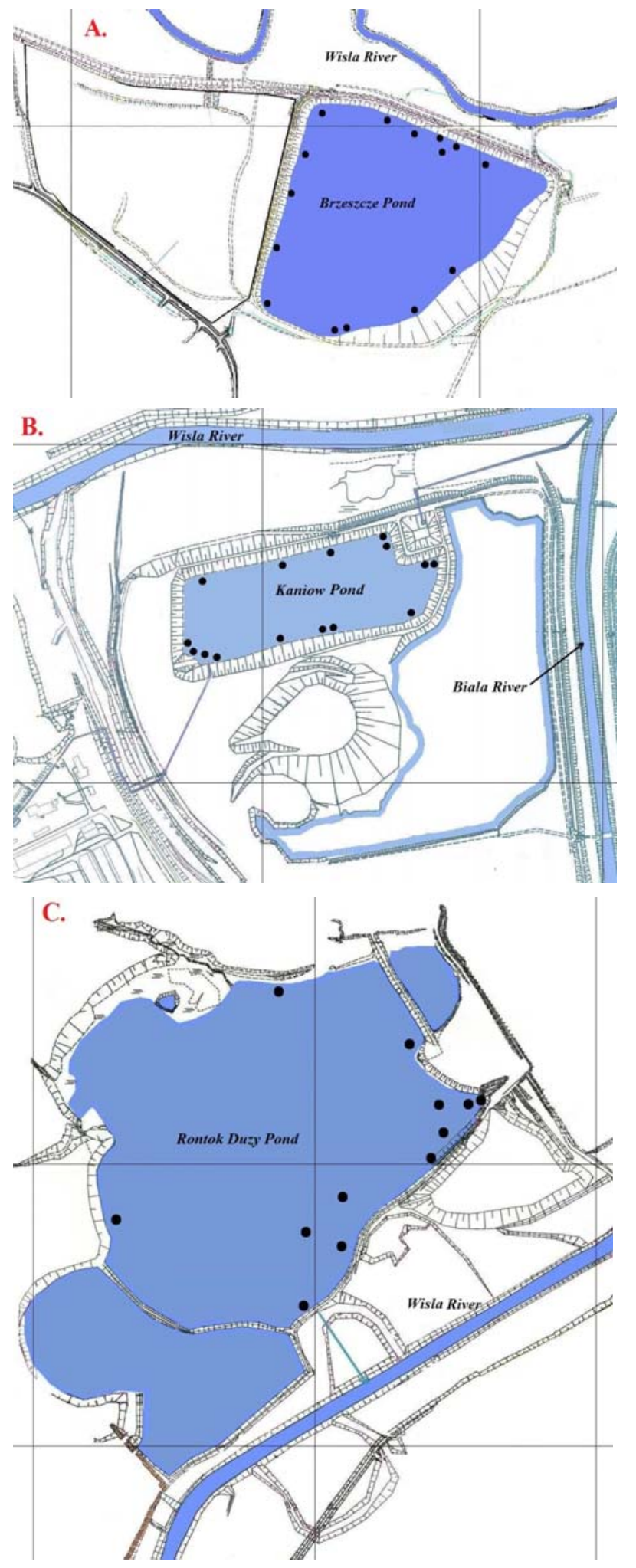

Fig. 2. The investigated area: (A) Brzeszcze pond, (B) Kaniów pond and (C) Rontok Duży pond. Black dots represent the individual sampling points of bottom sediments. of all radiological exposure indices, the ${ }^{228} \mathrm{Th}$ activity was consequently used in place of ${ }^{232} \mathrm{Th}$.

\section{$f_{1}$ and $f_{2}$ factors}

The $f_{1}$ activity factor defines the content of natural radioactive isotopes such as radium ${ }^{226} \mathrm{Ra}$, thorium ${ }^{228} \mathrm{Th}$ and potassium ${ }^{40} \mathrm{~K}$ in materials and wastes used as construction materials. It describes the full body exposure to gamma radiation from these radionuclides. The $f_{2}$ factor informs indirectly about the radiation exposure of radon and its short-lived decay products $[8,9]$.

The $f_{1}$ and $f_{2}$ factors are defined by the following equations:

$$
\begin{aligned}
& f_{1}=\frac{C_{\mathrm{K}}}{3000 \mathrm{~Bq} \cdot \mathrm{kg}^{-1}}+\frac{C_{\mathrm{Ra}}}{300 \mathrm{~Bq} \cdot \mathrm{kg}^{-1}}+\frac{C_{\mathrm{Th}}}{200 \mathrm{~Bq} \cdot \mathrm{kg}^{-1}} \\
& f_{2}=C_{\mathrm{Ra}}
\end{aligned}
$$

where $C_{\mathrm{K}}, C_{\mathrm{Ra}}$ and $C_{\mathrm{Th}}$ are the activity concentrations of ${ }^{40} \mathrm{~K},{ }^{226} \mathrm{Ra}$ and ${ }^{228} \mathrm{Th}$ (in $\mathrm{Bq} \cdot \mathrm{kg}^{-1}$ ), respectively.

For building and waste materials, regulation of the Polish Ministry Board gives admissible values of $f_{1}$ and $f_{2}$ coefficients, depending on the type of construction and its purpose:

1) $f_{1}=1 ; f_{2}=200 \mathrm{~Bq} \cdot \mathrm{kg}^{-1}$ for the building materials used in buildings intended for human or livestock accommodation,

2) $f_{1}=2 ; f_{2}=400 \mathrm{~Bq} \cdot \mathrm{kg}^{-1}$ for waste products used in buildings placed on built-up area or for levelling of land designated for construction area,

3) $f_{1}=3.5 ; f_{2}=1000 \mathrm{~Bq} \cdot \mathrm{kg}^{-1}$ for waste products used in buildings and for levelling of land designated for construction area not listed in 2), and

4) $f_{1}=7 ; f_{2}=2000 \mathrm{~Bq} \cdot \mathrm{kg}^{-1}$ for waste products used in underground construction (railways and road tunnels).

Additionally, on the areas where industrial wastes were used for levelling, construction of roads or sport and recreation objects the absorbed dose rate at $1 \mathrm{~m}$ above ground level should be reduced to value not exceeding $0.3 \mu \mathrm{Gy} \cdot \mathrm{h}^{-1}$, in particular by covering an additional layer of other materials.

\section{Radium equivalent}

Radium equivalent $\mathrm{Ra}_{e q}$ is defined by equation [11]:

$$
\mathrm{Ra}_{e q}=C_{\mathrm{Ra}}+1.47 C_{\mathrm{Th}}+0.077 C_{\mathrm{K}}
$$

where $C_{\mathrm{K}}, C_{\mathrm{Ra}}$ and $C_{\mathrm{Th}}$ are the activity concentrations of ${ }^{40} \mathrm{~K},{ }^{226} \mathrm{Ra}$ and ${ }^{232} \mathrm{Th}$ (in $\mathrm{Bq} \cdot \mathrm{kg}^{-1}$ ), respectively.

It is assumed that $\mathrm{Ra}_{e q}=370 \mathrm{~Bq} \cdot \mathrm{kg}^{-1}$ is a limit value below which the radiological exposure is treated as negligible.

\section{External and internal hazard indices}

The value of the external exposure index $H_{\text {ex }}$ is defined by equations $[10,11]$ : 


$$
\begin{aligned}
H_{e x} & =\frac{C_{\mathrm{Ra}}}{370 \mathrm{~Bq} \cdot \mathrm{kg}^{-1}}+\frac{C_{\mathrm{Th}}}{259 \mathrm{~Bq} \cdot \mathrm{kg}^{-1}} \\
& +\frac{C_{\mathrm{K}}}{4810 \mathrm{~Bq} \cdot \mathrm{kg}^{-1}}
\end{aligned}
$$

where $C_{\mathrm{K}}, C_{\mathrm{Ra}}$ and $C_{\mathrm{Th}}$ are the activity concentrations of ${ }^{40} \mathrm{~K},{ }^{226} \mathrm{Ra}$ and ${ }^{232} \mathrm{Th}$ (in $\mathrm{Bq} \cdot \mathrm{kg}^{-1}$ ), respectively.

The external hazard index is closely related to the radium equivalent $\mathrm{Ra}_{e q}$. The value of $H_{e x}=1$ corresponds to the radium equivalent $\mathrm{Ra}_{e q}$ equal to $370 \mathrm{~Bq} \cdot \mathrm{kg}^{-1}$. At this index value, radiological exposure is treated as negligible.

Apart from external index, an internal hazard index $H_{\text {in }}$ is defined $[10,11]$. It expresses a threat from radon and its short-lived decay products and is defined by the equation:

$$
\begin{aligned}
H_{\text {in }} & =\frac{C_{\mathrm{Ra}}}{185 \mathrm{~Bq} \cdot \mathrm{kg}^{-1}}+\frac{C_{\mathrm{Th}}}{259 \mathrm{~Bq} \cdot \mathrm{kg}^{-1}} \\
& +\frac{C_{\mathrm{K}}}{4810 \mathrm{~Bq} \cdot \mathrm{kg}^{-1}}
\end{aligned}
$$

where $C_{\mathrm{K}}, C_{\mathrm{Ra}}$ and $C_{\mathrm{Th}}$ are the same as mentioned earlier.

The limit value of this coefficient is 1 , which corresponds to half of the maximum permissible concentration of radium ${ }^{226} \mathrm{Ra}$.

\section{Absorbed dose rate $1 \mathrm{~m}$ above the ground level}

Total absorbed dose rate $D$ is defined by equation [12]:

$$
D=0.462 C_{\mathrm{Ra}}+0.604 C_{\mathrm{Th}}+0.041 C_{\mathrm{K}}
$$

where $D$ is the absorbed dose rate at $1 \mathrm{~m}$ above the ground level (in $\mathrm{nGy} \cdot \mathrm{h}^{-1}$ ), $C_{\mathrm{K}}, C_{\mathrm{Ra}}$ and $C_{\mathrm{Th}}$ are the activity concentrations of ${ }^{40} \mathrm{~K},{ }^{226} \mathrm{Ra}$ and ${ }^{232} \mathrm{Th}$ (in $\mathrm{Bq} \cdot \mathrm{kg}^{-1}$ ), respectively.

In calculations, the presence of other radionuclides such as cesium ${ }^{137} \mathrm{Cs}$, strontium ${ }^{90} \mathrm{Sr}$ and other isotopes from uranium series is neglected because of their low concentration in materials and thereby a small contribution to the absorbed dose.

\section{Results and discussion}

Results of radium ${ }^{226} \mathrm{Ra}$, thorium ${ }^{228} \mathrm{Th}$ and potassium ${ }^{40} \mathrm{~K}$ activity measurements and calculated indices of radiological hazard for waste rocks and bottom sediments are presented in Table 1.

The typical activities of natural radionuclides in rocks and sediments at the area of Poland are given in Radiological Atlas of Poland 2005 [13]:

- radium ${ }^{226} \mathrm{Ra}$ - from 4.2 to $116 \mathrm{~Bq} \cdot \mathrm{kg}^{-1}$; mean $25 \mathrm{~Bq} \cdot \mathrm{kg}^{-1}$,

- thorium ${ }^{228} \mathrm{Th}$ - from 3.6 to $82.8 \mathrm{~Bq} \cdot \mathrm{kg}^{-1}$; mean $23.4 \mathrm{~Bq} \cdot \mathrm{kg}^{-1}$,

- potassium ${ }^{40} \mathrm{~K}$ - from 60 to $1028 \mathrm{~Bq} \cdot \mathrm{kg}^{-1}$; mean $408 \mathrm{~Bq} \cdot \mathrm{kg}^{-1}$.

As shown in Table 1, the measured activities of these three radionuclides in bottom sediment samples collected from all investigated tanks exceed

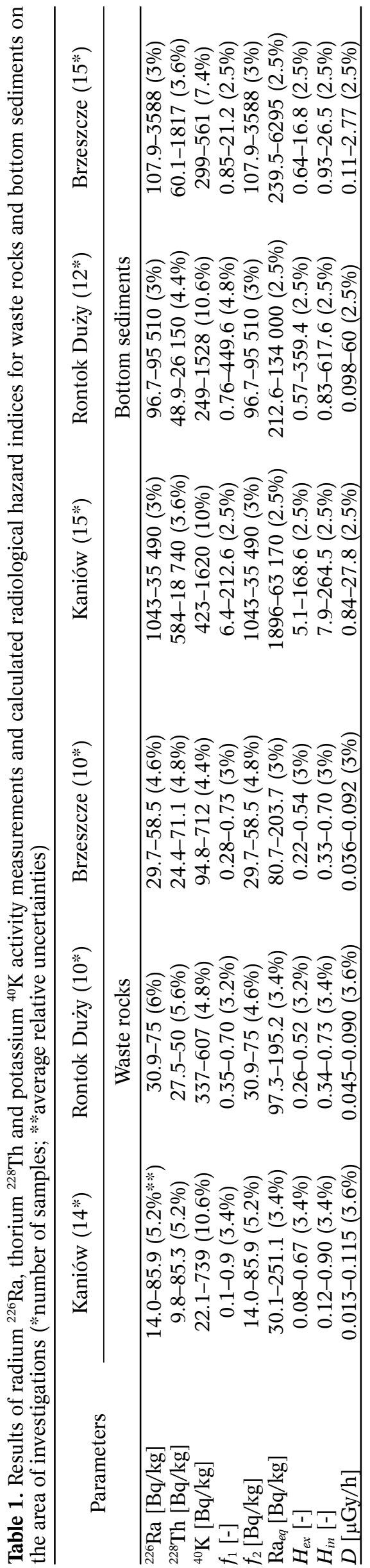


typical values for the territory of Poland. Specific activities of the individual isotopes in the bottom sediments from the Brzeszcze pond are in the range 107.9-3588 Bq $\cdot \mathrm{kg}^{-1}$ for ${ }^{226} \mathrm{Ra}, 299-561 \mathrm{~Bq} \cdot \mathrm{kg}^{-1}$ for ${ }^{40} \mathrm{~K}$ and $60.1-1817 \mathrm{~Bq} \cdot \mathrm{kg}^{-1}$ for ${ }^{228} \mathrm{Th}$. The activities of sediments from the Kaniów pond are between 1043 and $35490 \mathrm{~Bq} \cdot \mathrm{kg}^{-1}$ for ${ }^{226} \mathrm{Ra}, 423$ and $1620 \mathrm{~Bq} \cdot \mathrm{kg}^{-1}$ for ${ }^{40} \mathrm{~K}$, and 584 and $18740 \mathrm{~Bq} \cdot \mathrm{kg}^{-1}$ for ${ }^{228} \mathrm{Th}$. For the Rontok Duży pond, isotope activities in bottom sediments are in the range of $96.7-95510 \mathrm{~Bq} \cdot \mathrm{kg}^{-1}$ for ${ }^{226} \mathrm{Ra}, 249-1528 \mathrm{~Bq} \cdot \mathrm{kg}^{-1}$ for ${ }^{40} \mathrm{~K}$ and $48.9-26150$ $\mathrm{Bq} \cdot \mathrm{kg}^{-1}$ for ${ }^{228} \mathrm{Th}$. The maximum values of activity concentration in bottom sediments of the Rontok Duży and Kaniów pond are observed in the water inflow zones. In general, in the Brzeszcze reservoir the activity concentrations in bottom sediments are lower than in the Kaniów and Rontok Duży ponds. It may reflect the different mineralogical compositions of sediments. In the Brzeszcze pond, the sediments are dominated by quartz and calcite while in Kaniów and Rontok Duży reservoirs kaolinite, muscovite and barite are the predominant mineralogical phases.

The observed variability of isotope activities of bottom sediments from individual ponds reflects also differences in chemical composition of inflowing mine waters. Water from the Silesia coal mine supplying Kaniów and, in the past - Rontok Duży pond, is enriched with radium, barium and sulphate ions. This leads to the precipitation of barium sulphate. As a consequence, the radium coprecipitation takes place. In contrast, water from the Brzeszcze mine is almost barium free and so the coprecipitation of radium is very limited. Additionally, radium and other isotopes can be buried in bottom sediments as a result of adsorption on the surface of settling particles. However, the studies of sedimentation and transport processes were beyond the scope of this work.

Specific activities of radionuclides observed in waste rock samples taken from all investigated sites fall within the range of typical values for the territory of Poland. In part of samples from the Kaniów pond, the observed level of ${ }^{40} \mathrm{~K}$ activity was even lower. Waste rocks in all sites located near the Brzeszcze, Kaniów and Rontok Duży ponds are similar in terms of their petrography. The highest concentration of radionuclides was measured in rocks dominated by silty and mudstone shales. The lowest isotope activities were recorded in coal, independent of its origin.

According to national and international regulations expressed in terms of indices of radiological hazard (Tables 1 and 2), gangue can be used as construction material even in densely populated areas. The $f_{1}$ and $f_{2}$ factors calculated for them are lower than 1 and $200 \mathrm{~Bq} / \mathrm{kg}$, respectively. The maximum value of radium equivalent is equal to $251.1 \mathrm{~Bq} / \mathrm{kg}$, whereas the internal and external hazard indices are lower than 1. Calculated values of the individual indices allow the use of gangue stored in repositories in the construction of roads, ponds and river embankments.

Bottom sediments from the Brzeszcze retention pond are suitable for underground construction (railways and road tunnels). Calculated $f_{1}$ and $f_{2}$



$\because 0 \dot{0} 0 \dot{0} 0$

$+1+1+1+1+1$

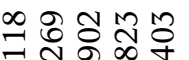

뭉ํㅇํ.

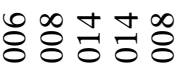

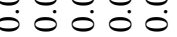

$+1+1+1+1+1$

엉욤

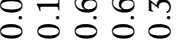

응 ปั่ ํํㅇ

0.

$+1+1+1+1+1$

m ำ 능 농

00000

0.000.

i $c$ in in

$+1+1+1+1+1$

$\rightarrow-\longrightarrow \ln \infty$

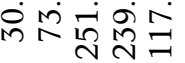

$+60 \mathrm{~N}$

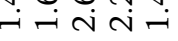

$+1+1+1+1+1$

○ 6 の

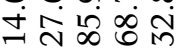

$0 \circ \infty \infty 0$

05050

00000

$+1+1+1+1+1$

ํㅡㄴ응ㅇㅇํํำ

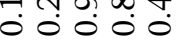

$+\infty$

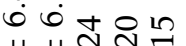

$+1 \sim N-$

$-a+1+1+1$

ㅊํㅁ용

$0+0 \infty \nabla$

$-i \sim$ i

$+1+1+1+1+1$

$\infty+N M 0$

の̊

$\forall 00 \%$

$+1+1+1+1+1$

$060 \wedge \infty$

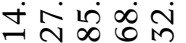

60 N

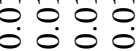
$+1+1+1+1$ 둥융 ○०००0.

$\forall ㅇ ㅡ ㅇ ㅇ$ 두잉 $+1+1+1+$ 공ำ 0000

ำ $\infty$ 응 웅 용 용 0000 $+1+1+1+$ 늠용ํㅇ ○잉 $\circ 000$ $0, \infty \infty$ $+1+1+1+1$ $\sim m \sim m$ $\hat{\circ} \infty \dot{\infty}$

N N $\sim$ i $+1+1+1+1$ n 1 L 1 ஸ் $\infty \forall 0$ 우웅 $+1+1+1+$ 송ㅇำ 0000

$N$ 규요 $+1+1+1$

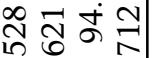

$\infty 0+0$ i $ن-1-1$ $-6+0$

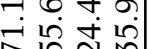
N 0 O 0 N $\mathrm{N}-$ $+1+1+1+1$ م $\mathrm{N}$ 人 虽 
coefficients for most of them are lower than 7 and $2000 \mathrm{~Bq} / \mathrm{kg}$, respectively. However, bottom sediments from Kaniów and Rontok Duży tanks may create serious problems in future because they do not meet radiological standards. As shown in Table 1, for these sediments all exposure factors are higher than recommended. For the Kaniów pond, the $f_{1}$ and $f_{2}$ factors for bottom sediments are between 14.4 and 212.6 and between 2394 and $35490 \mathrm{~Bq} / \mathrm{kg}$, respectively. The maximum value of radium equivalent is equal to $63170 \mathrm{~Bq} / \mathrm{kg}$, which is exceeding 170 times the value representing negligible radiological exposure. The absorbed dose rate is also very high, between 0.8 and $27.8 \mu \mathrm{Gy} / \mathrm{h}$. For the Rontok Duży reservoir, the maximum value of $f_{1}$ factor is close to 450 and $f_{2}$ is greater than $95500 \mathrm{~Bq} / \mathrm{kg}$. Both internal and external hazard indices calculated for bottom sediments are in most instances greater than 1 (maximum value are equal to 618 and 359, respectively). The maximum value of the absorbed dose rate is equal to $60.0 \mu \mathrm{Gy} / \mathrm{h}$.

\section{Conclusions}

The results of the performed isotope investigations indicate the possibility of disposal of waste rocks from the Brzeszcze and Silesia coal mines. They can be used as materials for surface or underground constructions. Gangue taken from both coal mines can be used as construction material even in the densely populated areas. It could also be used for the construction of roads or ponds and river embankments and for levelling of land designated for construction area. Bottom sediments from the Brzeszcze retention pond are suitable for underground construction (railway and road tunnels).

Radiological hazard indices calculated for bottom deposits of Kaniów and Rontok Duży reservoirs exceed many times the values recommended in legal acts. These sediments in their pure form are not suitable for any use in construction industry. Reclamation of these deposits will create a serious problem in the future.

Acknowledgment. This work was supported by statutory funds of the AGH University of Science and Technology (project no. 11.11.220.01/1) and by grant for $\mathrm{PhD}$ students (project no. 15.11.220.717).

\section{References}

1. Polish Ministry Board. (2002, October). The order of Polish Ministry Board from 29.10.2002 on the national waste management plan. Monitor Polski, 2003, no. 11, item 159 (in Polish).

2. Zalewski, M., Tomczak, M., \& Kapata, J. (2001). Radioactivity of building materials available in northeastern Poland. Pol. J. Environ. Stud., 10(3), 183-188.

3. Piotrowska, B., Fujak, M., Isajenko, K., \& Krawczyńska, S. (2016). Building materials radioactivity in Poland. Bezpieczeństwo i Technika Pożarnicza , 44(4), 151-158 (in Polish).

4. Pawuła, A. (1998). On the need for use of radiologic criteria in construction site evaluation. In Symposium: Recent Engineering Geological Problems in Poland (pp. 83-88). Poznań: Instytut Geologii UAM, WIND (in Polish).

5. Central Laboratory of Radiation Protection. (2014). Analysis of the natural radioactivity of raw and building materials in Poland in the period 1979-2012. Warsaw: CLOR.

6. Canberra. (2002). Detector specifications and performance data-Model GX4020 - 7915,30, S/N b 01010.

7. Jodlowski, P. (2005). Spektrometria promieniowania gamma prób środowiskowych; nuklidy promieniotwórcze w środowisku przyrodniczym Gorców. Unpublished Ph.D. Thesis, AGH University of Science and Technology, Kraków.

8. Council of Ministers. (2007, January). Regulation of the Council of Ministers of 2 January 2007 on the requirements for the content of natural radionuclides potassium ${ }^{40} \mathrm{~K}$, radium ${ }^{226} \mathrm{Ra}$ and thorium ${ }^{228} \mathrm{Th}$ in row materials used in residence intended for human and livestock and also industrial waste used in construction and control of the content of these isotopes. Dz.U., 2007, no. 4, item 29 (in Polish).

9. European Commission. (1999). Radiation Protection 112: Radiological Protection Principles Concerning the Natural Radioactivity of Building Materials. Directorate - General Environment. Nuclear Safety and Civil Protection.

10. UNSCEAR. (2000). Sources and effects of ionizing radiation. Report of the United Nations Scientific Committee on the Effects of Atomic Radiation to the General Assembly. New York, USA.

11. Beretka, J., \& Mathew, P. J. (1985). Natural radioactivity of Australian building materials. Industrial wastes and by-products. Health Phys., 48, 87-95.

12. Yu, K. N., Guan, Z. J., Stokes, M. J., \& Young, E. C. M. (1992a). The assessment of the natural radiation dose committed to the Hong Kong people. J. Environ. Radioact., 17, 31-48.

13. Central Laboratory of Radiation Protection. (2006) Radiological atlas of Poland 2005. Warsaw: CLOR. 